\title{
Large-Scale Investment in Biofuel Feedstock Production and Emerging Land Issues in Ghana
}

\author{
Joseph Kwaku Kidido \\ Department of Land Economy \\ Kwame Nkrumah University of Science and Technology (KNUST) \\ Kumasi- Ashanti Region, Ghana \\ Tel: +233-242-523-182 E-mail: jkidido@yahoo.co.uk \\ Elias Danyi Kuusaana (Corresponding author) \\ Department of Economic and Technological Change \\ Centre for Development Research (ZEF), Bonn, Germany \\ Tel: +49-176-732-56792 E-mail: ekuusaana@yahoo.com
}

\author{
Received: February 14, 2014 Accepted: March 7, $2014 \quad$ Published: March 8, 2014 \\ doi:10.5296/jsss.v1i2.5114 URL: http://dx.doi.org/10.5296/jsss.v1i2.5114
}

\begin{abstract}
The desire to increase global biofuel production and consumption in recent times is fuelling conversion of vast arable lands from food production to the cultivation of biofuel feedstock in some regions of the world. In the case of Ghana; the increasing trends of jatropha cultivation in the transition forest zone and the northern savannah belt of the country for biofuel is raising serious concerns about food security. Evidence exists of some local farmers been displaced from their ancestral farmlands while substantial alternative land is laying idle elsewhere in the country. Following this, there is the need for a better land use policy, proper land use planning and strategic location of the biofuel production fields in Ghana with models that effectively integrate smallholders into large investment projects in a manner that averts displacement of vulnerable local inhabitants and threatens local level food security. Hence we propose out-grower schemes and market integration for smallholders and not just large contiguous nucleus farms.
\end{abstract}

Keywords: Land, Biofuel feedstock, Jatropha, Investment and Ghana 


\section{Introduction}

The spiralling crude oil prices and uncertainties of future crude supplies as well as increasing need to diversify energy sources to more renewable alternatives to combat the threat of climate change are propelling many countries to seek alternative renewable sources of energy. Biofuels are being promoted on large scale as an alternative renewable source of energy and a means of reducing net greenhouse gas emissions to combat the threat of climate change. Biofuels are renewable fuels derived from biological feedstock, and include both liquid forms such as bio-ethanol (gasoline-equivalent) or biodiesel (diesel-equivalent), and gaseous forms such as biogas (e.g. methane) or hydrogen (Koh \& Ghozoul, 2008). Globally, the main sources of raw material for biofuel production are crops such as corn, sugar cane, oil palm, sugar-rich crops and also from grasses, trees, agricultural residues, and municipal wastes.

Biofuels can theoretically be carbon neutral as the carbon dioxide emitted during biofuel burning process is absorbed back by plants during growth, and hence substituting biofuels with fossil fuels has the potential to reduce GHG emission (Teitenberg \& Lewis, 2009; WWI, 2006). They also offer energy security benefits (Burgess and Morris, 2009) and opportunities for rural development (FAO, 2008c). According to Fargionel et al. (2008), land use change from forests to large-scale biofuel production can create a "biofuel carbon debt" by releasing 17-140 times more carbon dioxide than the annual green house gas (GHG) reduction that biofuels are expected to achieve by replacing fossil fuels. Biofuels obtained from beet, rapeseed, straw and cereals can contribute about $10-80 \%$ reduction in GHG emissions depending on farming practices (Royal Society, 2008). Though biofuel use is not entirely carbon neutral because of the GHG emissions involved in production, they remain preferable than fossil fuels.

Many governments including those of China, India, Brazil, the USA and the EU have set targets to use biofuel in their transport sector (Cotula et al., 2008a), and have introduced incentives and subsidies for biofuel production. In the USA, the annual biofuel subsidies is about 11-13 US\$ billion (IFPRI, 2008), and EU producers of biofuel feedstock receive about US $\$ 5$ billion a year (FAO, 2008c) as incentives. In 2006, biofuel represented only $1 \%$ of the total global fuel for transportation (IEA, 2006). Table 1 below provides a summary of some of the compiled data on biofuel production per the big regional block identified.

Table 1. Summary of biofuel production

\begin{tabular}{lll}
\hline Country & Biofuel production & Note \\
\hline United States & 31.85 billion litres of ethanol & US ethanol production capacity in 2007 \\
EU & 8.65 billion litres of biodiesel & EU biodiesel production in 2007 \\
China & 2000 million litres of ethanol & China ethanol production in 2006 \\
India & 300 million litres of ethanol & India ethanol production in 2006 \\
\hline Worldwide & 62 billion litres of ethanol and & Global ethanol and biodiesel production \\
& 10 billion litres of biodiesel & values for 2007 \\
\hline
\end{tabular}

Source: Compiled by Authors, 2013. 
Ethanol production worldwide tripled between 2000 and 2007 to reach 62 billion litres and biodiesel increased to over 10 billion litres (FAO, 2008c). In Brazil, ethanol accounts for over $40 \%$ of the fuel needs of its gasoline-powered vehicles and as of the end of 2007, the US had 135 active ethanol plants capable of producing more than 31.85 billion litres ( 7 billion gallons) of ethanol per year (Keeney \& Nanninga, 2008). Again, China's production of ethanol in 2006 amounted to 2000 million litres and India annual production stands at 300 million litres (WWI, 2006). Additionally, EU countries, the world largest producers of biodiesel also increased their production from 2.05 billion litres in 2004 to 8.7 billion litres (1.9 billion gallons) in 2007 (Mitchell, 2008). Ethanol production is predicted to increase to about 132 billion litres (29 billion gallons) in 2030 representing $20 \%$ of total gasoline consumption (EIA, 2009). Biofuel production has been increasing gradually since 1981 but witnessed drastic increases after 2001 (Figure 1) and the targets being set across the world would make it more prominent in the arena of world energy sources.

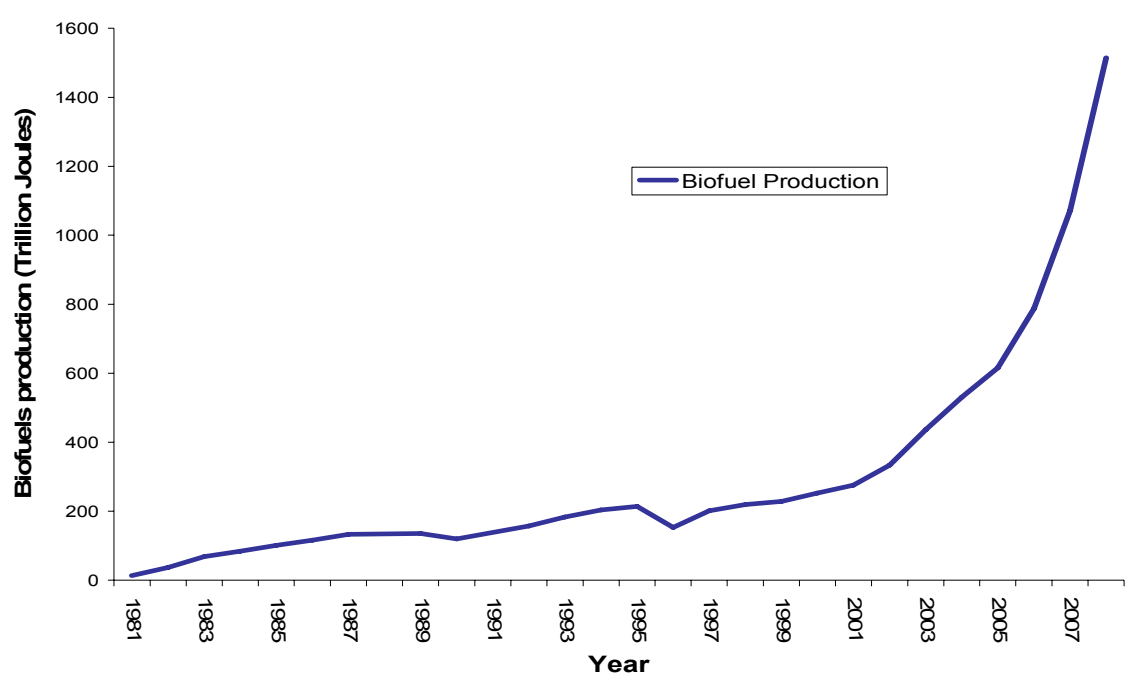

Figure 1. Worldwide biofuels production between 1981 and 2008

Source: EIA, 2008.

The rising production of biofuel globally poses enormous effects on land use and livelihoods of the rural communities who are most depended on the resources needed for this biofuel production. It is important to understand how the growing interest and investment in the biofuel are shaping land access rights and livelihoods of rural farmers. This paper focuses on recent upsurge in jatropha production for biofuel in Ghana and the emerging issues of land rights and livelihoods of the local communities and the models and policy interventions required.

\section{How much Land is Availability to Support Biofuel Production?}

Increasing production of biofuel will displace the production of food crops for human consumption from productive arable lands (Rahman et al., 2008) and this has ramifications for food security especially for already vulnerable women headed households. The Global Agro-ecological Assessment by Fisher et al. (2002), as reported by Cotula et al. (2008b) 
estimates that, globally, there are 2.5 billion ha of land in "very suitable" and "suitable" classes of potential for biofuel cultivation and another 784 million ha in the "moderately suitable" category. IEA (2006) estimated that 14 million ha of land (approximately $1 \%$ of the worldwide available land) was used for the production of biofuel and further projects 35 million ha (2.5\% of globally available land) would be required to meet the projected growth in biofuel production by 2030. Rathmann et al. (2009), report that $2.85 \%$ of the world arable land was already used to produce biofuel feedstock in 2007. In the 2006/07 crop year about 19 million ha of arable land in the six top biofuel producing countries was used to produce biofuel feedstock. The USA used $5.1 \%$ of its arable land while the EU used $4.4 \%$ for biofuel production in the 2006/07 crop season (USDA, 2008). Another study reports that globally, $9 \%$ of land areas for cereals, oilseed and sugar would be needed in order to attain a $10 \%$ biofuels share of transport energy (DEFRA, 2008).

Though the current amount of land used for biofuel production globally is relatively small compared to land used for food production, these estimates show the proportion is progressively becoming larger as biofuel production expands. What is of serious concern is the shifting interest of biofuel-driven countries to produce their feedstock from 'idle or underutilised' lands in African countries. Developing countries are targets for these investments motivated by low production cost, availability of water and land coupled with favourable climatic conditions for the production of the preferred crops of the investors (IFPRI, 2009). Developing countries with abundant supply of land will serve as the supply point for the energy and agricultural product needs of Europe and other parts of the world where these investors originate. For instance, it is estimated that nearly $60 \%$ of land needed to meet Europe's demand for agriculture products and energy comes outside of European region (FEE, 2011).

Though these emerging new opportunities proffer lots of benefits to smallholder farmers in Africa, the extent of the net benefits to be realised from these large scale investments hinges on the robustness of the regulatory institutions and the commitment of the political and community leaders to enter into well-thought-through deals with the investors. This emerging interest in land acquisition for biofuel production continues to raise grabbling concerns about wrongful expropriation, food insecurity, distress land transactions and land tenure insecurity for smallholders and more especially for vulnerable groups such as women and settler farmers. It also raises concerns about smallholder interests to adopt soil improvement practices such as land fallowing, land rotation, organic manure application, terracing and mulching since tenure insecurity is associated with such large land acquisitions.

Indeed land access and tenure insecurity of rural farmers, and food production are becoming serious problems in Africa and Asia due to increasing demand for alternatively cheaper land for biofuel production. For instance, in the Tanzanian Wami Basin over a thousand rural rice farmers have been reported displaced by large-scale sugar cane cultivation for the production of bio-ethanol by investors (Cotula et al., 2008b). In Benin, investors are proposing to cultivate between $300,000-400,000$ ha of palm oil for biofuel in the southern part of the country and about 500,000 ha oilseed production is been proposed by the South African government for biofuel (Ibid). It must also be stated, that, the amount of land diverted from food production to produce biofuel has some impact on the tightening land supply and 
increasing prices of grains.

It is further feared, the situation could seriously undermine future food security in these regions especially in Sub-Saharan Africa. In line with this, this study explores the activities of large land acquisition for biofuel production in Ghana and the effects on land allocation for food production in host communities.

\section{Methodology}

The study relied extensively on literature to gather the required secondary data and other relevant information on the growing production of biofuel and investments thereof. The information on the levels of land acquisition for the cultivation of biofuel feedstock in Ghana was also obtained from secondary sources including published papers and the database of Ghana Investment Promotion Centre (GIPC). We also undertook field visits in October 2012 and February, 2013 to some communities (Bredie-Camp, Dukusen and Afrisire) hosting large scale jatropha production in the Brong Ahafo and Ashanti Regions of Ghana to collect some qualitative data. Besides interviews with key stakeholders, there were also three focus group discussions, one at the Bredi-Camp in the Brong Ahafo Region and two at Dukusen and Afrisire in the Ashanti Region to gather qualitative data regarding how lands were acquired and the problems created for rural farmers and local food producers. For data on jatropha projects in Ghana, we looked at those that were established between 2005 and 2013 which in our view coincided with the global crises that precipitated the new momentum in biofuel investments.

\section{Biofuel Feedstock Production and the Emerging Issues in Ghana}

Ghana is located on the west coast of Africa and occupies a total land area of 238, 540 square kilometres. In Ghana the agricultural sector is the backbone of the economy, accounting for 34 percent of GDP and employing 55 percent of the economically active population (Deininger et al., 2011). The agricultural sector is controlled largely by smallholder farmers, who account for almost 90 percent of landholdings and approximately 80 of agricultural output (Chamberlin, 2008; Dinye, 2013). In this regard, Foreign Direct Investment (FDI) in the sector could strongly contribute to smallholder productivity, improve market access through the provision of rural infrastructure, enhancing their access to agricultural inputs, increasing their participation in global commodity markets (see von Braun and Meinzen-Dick, 2009; Schoneveld et al., 2010) and injecting into the sector the needed capital requirement after many years of governmental investment neglect.

In recent years, there is evidence of rapidly increasing agricultural FDI to Ghana for the cultivation of biofuel feedstock. However, little conclusive evidence is available on the scale and implications of this trend. A number of foreign firms have since 2006 arrived in Ghana particularly in the Northern Savannah Ecological Zone (NSEZ) requesting land to cultivate mostly jatropha, cassava and palm oil (see Table 2) for the biofuel industries abroad. A number of these companies have become defunct partly attributable to funding difficulties caused by the 2008 financial meltdown (Boamah, 2011), and local community agitations for the restoration of acquired ancestral lands. It is also the case that some investors rushed into agriculture especially jatropha as an alternative investment after the global financial crises without undertaking thorough due diligence or even without any previous experiences in 
farming. Table 2 below shows some of the biofuel companies in Ghana and the amount of land acquired for the cultivation of jatropha for biofuel production for the period between 2005 and 2013.

Table 2. Land acquired for jatropha production by biofuel companies in Ghana

\begin{tabular}{|c|c|c|c|c|}
\hline Name of Farm & Location/Region & $\begin{array}{l}\text { Year } \\
\text { Established }\end{array}$ & $\begin{array}{l}\text { Area of } \\
\text { Land } \\
\text { Acquired in } \\
\text { Hectares }\end{array}$ & $\begin{array}{l}\text { Area of Land } \\
\text { Cultivated in } \\
\text { Hectares }\end{array}$ \\
\hline $\begin{array}{l}\text { Savannah Black } \\
\text { Farming \& Farm } \\
\text { Mgt Ltd }\end{array}$ & $\begin{array}{l}\text { Ahinakom, Brong } \\
\text { Ahafo region }\end{array}$ & 2006 & 202.34 & 121.41 \\
\hline Jatropha Africa & $\begin{array}{l}\text { Kintampo South, } \\
\text { Brong Ahafo Region }\end{array}$ & 2007 & 50,000 & 202.34 \\
\hline Bio-fuel Africa & $\begin{array}{l}\text { Kpachaa, Northern } \\
\text { Region }\end{array}$ & 2007 & 10,696 & 1,000 \\
\hline $\begin{array}{l}\text { Integrated Tamale } \\
\text { Fruit Company- } \\
\text { (ITFC) }\end{array}$ & $\begin{array}{l}\text { Dipale, Gushie and } \\
\text { Tunayilli, Northern } \\
\text { Region }\end{array}$ & 2001 & 1,363 & 600 \\
\hline Smart Oil & $\begin{array}{l}\text { Yeji, Brong - Ahafo } \\
\text { Region }\end{array}$ & 2008 & 50 & 50 \\
\hline Kimminic Estates & $\begin{array}{l}\text { Bredie No. 1, Brong } \\
\text { Ahafo Region }\end{array}$ & 2008 & $12,140.57$ & $6,070.28$ \\
\hline ScanFarm Ltd & $\begin{array}{l}\text { Agogo, } \quad \text { Ashanti } \\
\text { Region }\end{array}$ & 2007 & 13,058 & 1000 \\
\hline Anuanom Farms & $\begin{array}{l}\text { Old Akrade-Juapong, } \\
\text { Eastern Region }\end{array}$ & 2006 & 404.70 & 121.41 \\
\hline Galten Agro Ltd & $\begin{array}{l}\text { Adidome, } \\
\text { Region }\end{array}$ & 2008 & 400 & 325 \\
\hline Bio-fuel Africa & Lolito, Volta Region & 2007 & 2,300 & Unknown \\
\hline Unknown & Prang & 2009 & unknown & 520 ha \\
\hline Unknown & $\begin{array}{l}\text { Atebubu, Brong } \\
\text { Ahafo Region }\end{array}$ & 2010 & 30,000 & Unknown \\
\hline $\begin{array}{l}\text { Jatropha Africa } \\
\text { (UK/Ghana) }\end{array}$ & $\begin{array}{l}\text { Domeabre, Brong } \\
\text { Ahafo Region }\end{array}$ & 2009 & 50,000 & Oha \\
\hline \multicolumn{3}{|l|}{$\sum($ Hectares of Land) } & $84,102.91$ & $8,200.44$ \\
\hline \multicolumn{2}{|c|}{ Total Acquired Land } & Total Cultivated Land & \multicolumn{2}{|c|}{ Total Abandoned Land } \\
\hline \multicolumn{2}{|l|}{$84,102.91$} & $8,200.44$ & \multicolumn{2}{|c|}{$75,902.47$} \\
\hline \multicolumn{2}{|l|}{ PERCENTAGES } & 9.75 & \multicolumn{2}{|l|}{90.25} \\
\hline
\end{tabular}

Source: Authors, 2013; IRIN (2009); Dogbevi (2009), GIPC (2013). 
From the data above, it is discovered that over $50 \%$ of these companies are located in the forest-savannah transition zone of Ghana's Brong Ahafo region and the northern part of the Ashanti region. However, only a fraction of these lands have actually come under cultivation, with no more than 10,000 hectares representing about $10 \%$ of Ghana's agricultural productive land likely to be under cultivation by these investors as indicated in Table 2 (see also Schoneveld et al, 2010). The largest contiguous areas under cultivation are located in the transition zone (i.e. around the Ashanti and Brong Ahafo regions of Ghana) where three plantations covering approximately 6,000 hectares, 1,000 hectares, and 202 hectares of land are established in Agogo, Bredie and Kintampo.

The government policy of having 10\% biofuel share of Ghana's total fuel content by 2015 has partly been a driving factor for the growing interest in biofuel. The consequence of this policy initiative and the investors' response is notable in the increased demand for rural agricultural land. Land area currently under jatropha production and the future production plans for this biomass in Ghana centre mainly on fallow agricultural lands and in some cases extended to lands under active cropping. This phenomenon has altered the farming environment of the affected communities. Some local farmers have been forced to abandon farming or relocate to alternative farmlands farther away from their settlements. In a previous case study by Schoneveld et al. (2010) in the Brong Ahafo and Ashanti Regions, revealed an approximately 800 hectares jatropha cultivation (from a 15,000 hectare lease) displaced an estimated 55 percent of usufructuary land and forced the relocation of 70 households from three communities. Though some chiefs granting these interests to the investors have argued that such lands are idle or abandoned, the reality is that most of these parcels of land remain active fallow lands and not 'idle or abandoned' as claimed. Under such circumstances, the few relatively endowed farmers are able to secure for themselves alternative farm lands in other locations of the same village or in other nearby communities, while the poor farmers are compelled to migrate in search of new farming parcels or make do with marginal communal lands or resort to sharecropping or short term leases.

\subsection{Lack of consultation and compensation for the local Landholders}

From our stakeholder consultations in Bredi, in the Brong Ahafo Region and Agogo in Ashanti, land users were in copious cases not properly consulted nor involved in any of the processes leading to the acquisition of lands by some of these companies. A resident in Bredi-Camp, a village in the Nkroranza South District of the Brong Ahafo Region of Ghana, laments lack of knowledge of the establishment of a jatropha plantation in their community. No prior consultation was done with them before their farms were even destroyed. "We woke up one morning and saw bulldozers, we thought they were here to construct our road but to our dismay, they started pulling down our plantains and other crops" (Interview, 2012). Another farmer, whose hamlet is located few kilometres from the Bredi-Camp, had had his settlement as well as his farm engulfed by a jatropha plantation. He narrates: "I refused to allow them to destroy my settlement and farm. I resisted with my gun any time they (company) attempted to pull down the structures. Because of this, they have established their plantation and left me in the middle. I have vowed not to relocate until I am duly compensated. When the company came, they employed me as a security guard, but because of my refusal to allow them access to the land I am occupying, they have sacked me, but I don't care" (Interview, 
2012). These two scenarios reaffirms an earlier report by IRIN (2009) which similarly revealed lack of consultation and payment of compensation in the acquisition of lands for jatropha plantation for biofuel in the Northern Region of Ghana. IRINS (2009) report quotes an affected farmer, who said: "There was no consultation with us (farmers) before the land was sold and I have not been paid any compensation since I was displaced". Though it is not intended to blame the largely foreign investors for the displacements recorded, we can confirm that most investors were wrongfully informed by community land trustees about the occupancy or use of these large lands acquired. They were made aware that these parcels were idle, unoccupied, underutilised and unused for farming activities, even when it was discovered that these parcels were either active fallow lands or cultivated lands.

In our study in Bredi, it was reported that no platform was created for the negotiation of compensation for even affected crops. All acquisition arrangements were concluded with the paramount stool and traditional council while completely ignoring lesser rights holders who had substantial investments on the land. In the case of ScanFarm (Gh) Ltd, the land users were not directly consulted but their village Chiefs (Odikro) were part of the council that negotiated and approved the transaction. Some farmers who lost usufructs rights were able to claim some compensation after a series of negotiations. An adjusted figure of GH $₫ 33$ per acre (instead of $\mathrm{GH} \notin 27$ that was professionally recommended by their valuation consultant) was paid to affected land owners together with lump sum payments made to the stool. However, settler farmers who were the actual land users were not compensated though they reportedly lost some farmlands and crops to the large concession.

This is contrary to the customary tenet on land ownership in Ghana which posits land as a communal asset (see Ollennu, 1962) and its disposal must involve principal stakeholders (see Sarbah, 1968: 67). Allodial title holders (i.e. the paramount stools) have by their actions flouted the well established principle regarding land alienation in Ghana especially when some of the affected farmers hold usufructuary rights. The courts in Ghana have on a number of occasions emphasised that allodial holders cannot arbitrarily dispossess usufructs without their consent and approval. For leading legal cases see Ohimen v Adjei and Another (1957) 2 WALR 275; Thompson v. Mensah (1957) W.A.L.R. 240; Baidoo v. Owusu (1957) W.A.L.R. 289; and Mansu v. Abboye and Another [1982-83] GLR 1313.

The Constitution of Ghana, under article 20 makes it mandatory for every land expropriation to be accompanied with prompt, fair and adequate compensation. Sadly, this has not been the case regarding some of the acquisitions we studied. Furthermore, according to Ollennu (1962), stools are not obliged to account for financial proceeds from land transactions. Hence it was not strange to have realised that affected communities had no idea about the monetary value of the land transactions. This disturbing practice led to the intervention of some NGOs and other agencies in charge of land and environment to impress on the companies involved in the inappropriate acquisition processes to respect the operating land tenure systems and legitimise their operations. For example, NGOs such as Regional Advocacy and Information Network Systems (RAINS) and Action Aid-Ghana, have played pivotal roles towards defending the rights of the local land users against these acquisitions in Kpachaa and Agogo. Even though some of these NGOs may have taken actions that overly exploited and exaggerated the repercussions of these biofuel investments out of proportions, the rather 
limited benefits from these investments must not blind a critical review of the land acquisition processes.

\subsection{Expectations and the reality in the host Communities}

Premised on job opportunities and improved livelihoods in the communities, large parcels of lands are generously offered for the cultivation of jatropha by the local traditional leadership oblivious of the apparent social and economic implications. Boamah (2011) recounts the hopes of a chief of Kusuwgu community in the Central Gonja District in allocating land to a biofuel company. The chief stated; "I decided to lease a land size of 300 hectares initially for the start of the project and if I find out any sign of positive development, then part of the vast idle land will be given to them to continue their operations. ... We need them because, we believe that their operations will generate employment for our people and create development for us" (Boamah, 2011: 7). Indeed it is heart-warming if large land acquisitions are accompanied with desirable cash-based on-farm or off-farm employment. However, where these fail to materialize, the expectations and hopes of many of the affected communities are dashed. It was our observation that host communities' expectations have generally failed to match up with actual benefits from large scale land acquisitions. Only a few job opportunities were created in Kpachaa and Bredi. Smallholders initially were offered jobs during the field clearance and stumping stages but afterwards, the focus shifted to women who were preferred to work in those farms. In Dukusen, our study revealed that ScanFarm (Gh) Ltd employed 55 permanent and a range of between 40 -100 casual workers depending on the peak of their operations. As a result of heavy mechanization being applied by the company, they are currently resorting to more seasonal and casual workers for de-stumping, stone picking, manual fertilizer application, cob picking and sometimes manual harvesting especially during heavy rainfalls when mechanization is impossible.

Noble as community expectations may be, the fundamental issue on the disruption to the livelihood and local landholding for farming is still critical. The reality has been the disproportionate reception of the concomitant negative outcomes vis-à-vis the actual benefits to the communities. A report by IRINS (2009) revealed the difficulties some of the affected farmers in Kpachaa were facing as a result of their land taken for biofuel cultivation. " $A$ few of the farmers were offered employment on the jatropha plantation but many others were left with hunger and no source of income, while others like myself had to raise money to rent another plot of land several kilometres away. It has been a very difficult time for my family" (IRINS, 2009). Though this is just a single reportage and should be interpreted carefully, it serves as a pointer to some of the hardships of expropriation which often hit smallholders in host communities. In some cases, valuable economic trees such as shea nut (butyrospermum parki) and dawadawa (paskia clappertomana) which provide income for especially women were reportedly destroyed to pave way for the preparation of jatropha farms.

Nyari (2009) noted of the frustration of a woman in Alipe, a village in the Central Gonja District in the Northern Region over the destruction of shea nut trees in the preparation of jatropha farms. "Look at all the shea-nut trees you have cut down already and considering the fact that the nuts that I collect in a year give me cloth for the year and also a little capital ... Now you have destroyed the trees and you are promising me something you do not want to commit yourself to. Where then do you want me to go? What do you want me to do? "(ibid: 6). 
In many patrilineal communities in the northern savannah belt of Ghana, women are entrusted only use rights to customary land and not ownership rights because of their dual relationship with both their marital and natal homes. If women are not economically sound to rent or buy a farmland, she may still have access to family land but on very weak tenure. However, with the recent activities of large land acquisitions, the plight of women may worsen. For example, women may be allocated marginal land, and may risk dispossession if that parcel is needed for some other use or for sale to resolve some family challenges.

4.3 In what ways will the problems continue to manifest in Ghana?

The current development in jatropha cultivation for biofuel in Ghana, if continued without appropriate remedial measures, undesirable outcomes on the host communities would continue to predominant. These outcomes from our study will be mainly but not limited to the following;

Local food security would be threatened should the status quo persist. A situation where prime agricultural lands as well as those already under some form of cropping or active fallowing system are converted to jatropha for biofuel, this has the potential for food shortages especially in the catchment areas of these on-going biofuel activities. Consequent to the production deficit of local staples, local food prices would increase in the local markets and this can unleash further repercussions on the already less resourced poor farmers. Though majority of Ghanaian farmers at one point in time, may have to resort to meeting their food supply needs from the local markets through purchase due to low or empty stocks at home, low productivity from family farms due to constrained access to viable land may exacerbate their year to year predicament of food insecurity. Invariably, they may be acquiring food at higher prices than they could produce locally themselves.

The other dimension worth policy attention is the exacerbation of landlessness and land tenure insecurity. Farmland is the most precious social and economic property of most rural agricultural households and guaranteed holding rights are immensely invaluable. Increased attention on rural farmlands for biofuel feedstock means some people need to be displaced either on their current farmlands, fallow lands or active fallow lands to pave way for the more resourceful i.e. both financial and power rated biofuel investors. If nothing is done to ameliorate the potential hazards, rural farmers risk losing land both as an economic good for production, store of wealth for collateralization and social asset as a sense of place.

Emigration from the affected farming communities is inevitable if landlessness and displacement become the persisting trait for jatropha production to occur in Ghana. The larger economic and social outcome of this biofuel-induced emigration can be disturbing. As a result, the already high level North-South youth migration in Ghana for menial jobs would exacerbate. At the end, it would be precarious if only the aged are left in origin communities to sustain food productivity. Thus, this is an area that requires policy intervention in Ghana and other parts of sub-Saharan Africa where climate induced migration is already a major concern.

Disruption of social and cultural life developed around ancestral land is yet another area of concern. People tend to develop emotional attachment as well as building their social life around ancestral land. Burial of loved ones and local heroes, shrines, sacred grooves and 
other social functions are major social connections to land. Large scale land acquisition and investments which tend to overwhelm small settler farming communities can create social discomfort. Popular community resistance against large scale agro-investments are engineered not only for economic reasons but importantly by the clarion need to protect social and cultural capital established on land. The activities of social activists and NGOs must however be non-parochial and non-overly sensationalised.

\section{Conclusion}

Investments in biofuel production and its perceived tendency to lessen the quantity of food on the table rather offers a challenging future for developing countries like Ghana with vast land already committed to jatropha. The investments in jatropha production in Ghana and the reported displacement of existing farms as well as active fallow lands to the detriment of local food production and rural business is a case requiring swift policy response. Since food is particularly sensitive and any reduction in its availability poses far reaching consequences on human lives, more restrain and prudence in land use is needed so as not to provoke any crisis in the food production.

The problems spilling from biofuel production on the local inhabitants need a holistic approach in order for Ghana's biofuel production to move on a sustainable path. Problems such as non-payment of compensation and; displacement of existing farms and active fallow lands can be averted if strict rules and procedures for land acquisition in Ghana are applied. Companies involved in jatropha production must also design social responsibility programmes for the locals. Employment and infrastructural services promised by the companies should indeed be documented and subsequently provided to these communities to gain the social licence they need from the local populace. Where this is not possible due to unforeseen hitches and financial constraints, a more subtle approach will be appropriate to communicate these challenges. Food production strategies involving support to local farmers and growing food crops alongside jatropha plantations are some of the distress alleviating measures worth employing by the biofuel firms. Alternatively, the acquisition of large stretch of land in one location could be substituted with moderate stretches in different communities so as not to overly inflict hardships on just a few communities whose limited productive lands i.e. including farmed lands, active fallow lands and inactive fallow lands may be affected. Investors should be encouraged to establish nucleus farms with out-grower schemes handled by smallholder farmers and with market integration.

Given the vast arable lands in the middle belt and in the northern part of Ghana, it is possible to contain biofuel production with minimal impact on local landholdings, livelihoods and food production. This can be achieved through strategic location of the biofuel farms away from the existing communities, farms and fallow lands. The unutilised arable lands in the savannah zone of the country could be carefully used so as not to compete with land access and challenge tenure security of the local farmers. Jatropha cultivation for biofuel should in no way compete with food production. Marginal lands under no form of cultivation should be targeted. Fertile lands used for jatropha should be done using more sustainable approaches especial those that will preserve soil fertility. In a region like the northern savannah zone of Ghana which is already threatened by climate change, large scale mechanised agriculture will have dire consequences for the environment. 
Notwithstanding the possible social and environmental mishaps of these biofuel activities in the country, some positive outcomes are felt in the catchment areas and such frontiers must be expanded. Indeed if the proper regulatory reforms are enacted in Ghana, opportunities inherent in the current surge in the foreign investment in land acquisitions for purposes including biofuel could be well harnessed to provide jobs and develop rural communities. Indeed employment with agro-investments reduces economic distresses of smallholders who lack additional income opportunities. However, it is not just enough to create a few jobs, but the creation of sustainable jobs and the possibilities of scaling up job opportunities should be the ultimate goal of these large-land investments.

The challenge of attaining sustainable biofuel production environment in Ghana lies with striking the balance between the land needed for food production and that required to satisfy the growing desire for energy from renewable sources without debilitating impacts on local food production, livelihoods of rural folks and environmental sustainability. Ascertaining the threshold for the occurrence of enormous repercussions of biofuel plantations on local food production and smallholder farmers is very critical. Broader consultation with the stakeholders in the energy sector, agriculture, land use planning and the local inhabitants is paramount in attaining a sustainable biofuel future for Ghana. Ghana particularly requires a biofuel production policy to set out the framework for sustainable production of biofuel in the country without compromising on local food security, land rights of smallholder farmers and environmental sustainability. In our opinion, the negative impact of biofuel production is not the biofuel itself, but the manner in which it is carried out - competing with active crop or fallow lands, limited consultations with local land users, exaggerated promises on jobs and social infrastructure and the wanton destruction of large tracks of economic trees even when such large parcels are not needed for immediate production.

\section{References}

Boamah, F. (2011). "The Relationship between Land Grabbing for Biofuels and Food Security, a Bane or Boon? The Food Security Implications of Jatropha Biodiesel Project in Northern Ghana" A Paper presented at the International Conference on Global Land Grabbing, 6- $8^{\text {th }}$ April, organized by Land Deals Politics Initiatives (LDIP).

Burgess, P. J., \& Morris, J. (2009). Agriculture Technology and Land Use Futures: The UK Case. Paper accepted by Land Use Policy.

Cotula, L., Dyer, N., \& Vermeulen, S. (2008a). Fuelling Exclusion? The Biofuels Boom and Poor People's Access to Land, International Institute for Environment and Development (IIED), London.

Cotula, L., Dyer, N., \& Vermeulen, S. (2008b). Bioenergy and Land Tenure; The Implications of Biofuels for Land Tenure and Land Policy, Land Tenure Working Paper 1, International Institute for Environment and Development (IIED). Retrieved from ftp://ftp.fao.org/docrep/fao/011/aj224e/aj224e00.pdf

DEFRA. (2008). The Impact of Biofuels on Commodity Prices, Department for Environment, Food and Rural Affairs, London. Retrieved from http://www.defra.gov.uk/ENVIRONMENT/climatechange/uk/energy/renewablefuel/pdf/biofu els-080414-4.pdf, Accessed on April 10, 2009 
Deininger, K. D., Byerlee, J., Lindsay, A., Norton, H., Selod, H., \& Stickler, M. (2011). Rising global interest in farmland: Can it yield sustainable and equitable benefits? Washington, D.C.: World Bank. http://dx.doi.org/10.1596/978-0-8213-8591-3

Dinye R. D. (2013). Irrigated Agriculture and Poverty Reduction in Kassena Nankana District in the Upper-East Region, Ghana. Journal of Science and Technology, 33(2), 59-72. http://dx.doi.org/10.4314/just.v33i2.6

EIA. (2009). "What are biofuels and how much do we use?" Energy Information Administration, US Department of Energy. Retrieved from http://tonto.eia.doe.gov/energy_in_brief/biofuels_use.cfm

FAO. (2008). The State of Food and Agriculture: Biofuels: prospects, risks and opportunities, Food and Agriculture Organisation, Rome, Italy. Retrieved from http://www.fao.org/sof/sofa/index_en.html

Fargione, J., Hill, J., Tilman, D., Polasky, S., \& Hawthorne, P. (2008). Land clearing and biological carbon debt. Science, 319(5867), 1235-1238. http://dx.doi.org/10.1126/science. 1152747

FEE. (2011). Europe‘s Land Import Dependency, Friends of the Earth Europe. Retrieved from http://bit.ly/NsC06F

Fischer, G., van Velthuizen H., Shah M., \& Nachtergaele, F. (2002). Global agro-ecological assessment for agriculture in the 21st century, International Institute for Applied Systems Analysis, Luxemburg, Austria and Food and Agriculture Organisation of the United Nations, Rome.

IEA. (2006). World Energy Outlook, International Energy Agency, Paris, France. Retrieved from http://www.iea.org/textbase/nppdf/free/2006/weo2006.pdf

IFPRI. (2008). High Food Prices: The What, Who and How of Proposed Policy Actions, Policy Brief, International Food Policy Research Institute. Retrieved from http://www.ifpri.org/PUBS/ib/FoodPricesPolicyAction.pdf

IFPRI. (2009). "Land Grabbing" by Foreign Investors in Developing Countries; Risks and Opportunities; International Food Policy Research Institute, Policy Brief 13. April 2009.

IRIN. (2009). Land grabs force hundreds off farms, growers say; Integrated Regional Information Networks (IRIN) News, Retrieved from http://www.irinnews.org/Report.aspx?ReportID=86044

Keeney D., \& Nanninga, C. (2008). Biofuel and Global Biodiversity, Institute for Agriculture and Trade Policy, Minneapolis, Minnesota. Retrieved from http://www.agobservatory.org/library.cfm?refid=102584

Koh, P. L., \& Ghozoul, J. (2008). Biofuels, biodiversity, and people: Understanding the Conflicts and Finding opportunities. Biological Conservation, 141, 2450-2460. http://dx.doi.org/10.1016/j.biocon.2008.08.005

Mitchell, D. (2008). A Note on Rising Food Prices, Policy Research Working Paper 4682, The World Bank Development Prospects Group. Retrieved from http://bit.ly/1q2inl0

Ollennu, N. A. (1962). Principles of Customary Land Law in Ghana. Sweet and Maxwell, London. 
Rathmann, R., Szklo, A., \& Schaeffer, R. (2009). Land use competition for production of food and liquid biofuels: An analysis of the arguments in the current debate. Renewable Energy, pp. 1-9.

Rahman, S. H., Ahmed, A. M., Bauer, A., Bhushan, I., Carrasco, B., Chatterjee, S., ... Alamgir, M. (2008). Soaring Food Prices: Response to the Crisis. Asian Development Bank, Manila, Philippines. Retrieved from http://www.adb.org/Documents/Papers/soaring-food-prices/soaring-food-prices.pdf

Royal Society. (2008). Sustainable biofuels: prospects and challenges. Retrieved from http://royalsociety.org/Sustainable-biofuels-prospects-and-challenges

Sarbah, J. M. (1968). Fanti customary laws (3rd ed.) Cass, London.

Schoneveld, C. G, German, A. L., \& Nukator, E. (2010). Towards Sustainable Biofuel Development: Assessing the Local Impacts of Large-Scale Foreign Land Acquisitions in Ghana.

Tietenberg, T., \& Lewis, L. (2009). Environmental and Natural Resource Economics (8th Ed.), Pearson Education, Inc. Boston.

USDA. (2008). Global Agricultural Supply and Demand: Factors Contributing to the Recent Increase in Food Commodity Prices, Economic Research Services, United States Department of Agriculture, Outlook Report No. WRS-0801, July (Revised). Retrieved from http://www.ers.usda.gov/Publications/WRS0801/WRS0801.pdf

USDA. (2009). Production, supply and distribution online, Foreign Agricultural Service, United States Department of Agriculture, Custom Query. Retrieved from http://www.fas.usda.gov/psdonline/psdquery.aspx

von Braun, J. \& Meinzen-Dick, R. (2009). "Land Grabbing” by Foreign Investors in Developing Countries: Risks and Opportunities. Policy Brief 13. IFPRI. Washington DC. Retrieved from http://www.ifpri.org/sites/default/files/publications/bp013all.pdf

WWI. (2006). Biofuels for Transportation; Global Potential and Implications for Sustainable Agriculture and Energy in the $21^{\text {st }}$ Century, Worldwatch Institute. Retrieved from http://www.worldwatch.org/system/files/EBF008_1.pdf

\section{Copyright Disclaimer}

Copyright reserved by the author(s).

This article is an open-access article distributed under the terms and conditions of the Creative Commons Attribution license (http://creativecommons.org/licenses/by/3.0/). 